\title{
Stabilization of the vaporization of the filled cathode in a d.c. carbon arc
}

\author{
M. F. A. Hoens and J. A. Smit \\ Physisch Laboratorium der Rÿks-Universiteit, Utrecht
}

\section{Introduction}

MitChell [1] describes a routine method for trace-element analysis of non-conductive samples. He employs the cathode-layer in a 9 amp d.c. carbon arc. Fig. 1 shows the dimensions of the electrodes [2]. The sample is pressed into a narrow hole in the narrow upper part of the lower electrode, the cathode. The electrode distance is kept constant at $15 \mathrm{~mm}$. The sample with the surrounding carbon wall evaporates within 3 minutes. During the evaporation the arc spectrum is photographed.

Table 1. Contents to be measured

\begin{tabular}{l|c|c|c}
\hline $\begin{array}{c}\text { Element } \\
\text { line } \\
\AA\end{array}$ & $\begin{array}{c}\text { Reference } \\
\text { line }\end{array}$ & $\begin{array}{c}\text { Initial } \\
\text { content, } \\
\text { in p.p.m. }\end{array}$ & $\begin{array}{c}\text { Spectrographic } \\
\text { suitable content, } \\
\text { in p.p.m. }\end{array}$ \\
\hline Co $3453\left(4 \mathrm{eV}^{*}\right)$ & Fe 3452 (5.8) & $0 \cdot 01-0 \cdot 5$ & $10-1000$ \\
Mo 3170 (3.95) & Fe 3197 (6.2) & $0 \cdot 1-15$ & $20-1000$ \\
$\mathrm{Zn} \mathrm{3345} \mathrm{(7.7)}$ & Fe 3261 (7.4) & $5-80$ & $200-20,000$ \\
Cu 3274 (3.8) & Ag 3281 (3.7) & $1-20$ & $20-5000$ \\
\hline
\end{tabular}

* This is the upper level energy of the line, in electron volts.

In our measurements according to this method, we analysed plant ashes and such-like mixtures, chiefly with respect to $\mathrm{Cu}, \mathrm{Co}$, Mo and $\mathrm{Zn}$ [3]. After a chemical pretreatment [3] the contents were e.g. 4, 0.01, 0.1 and 5 per thousand respectively. Table 1 shows the initial contents and the spectrographic measurable contents; the pretreatment bridges the difference.

Without special precautions the measurements showed standard deviations of about 10 per cent and more (apart from possible systematic errors). The standard deviation in the photographic relative intensity measurements alone was 4 per cent max.; with photo-electric measurements this could be reduced to 1 per cent [4]. Apparently the largest errors were introduced by the chemical pretreatment and by the light source. We have tried to improve the source to raise the accuracy.

\section{Errors and improvements}

(1) Irreproducibility of the arc spectrum caused by inhomogeneity of the sample was not the most important factor in the discrepancies. We ground our samples during 15 minutes. Longer grinding time than 10 minutes did not decrease the standard deviation. 
Stabilization of the vaporization of the filled cathode in a d.c. carbon arc

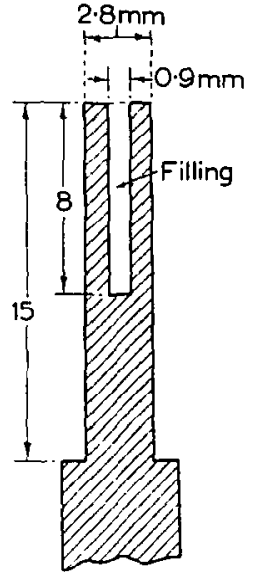

Fig. 1. Cathode dimensions.

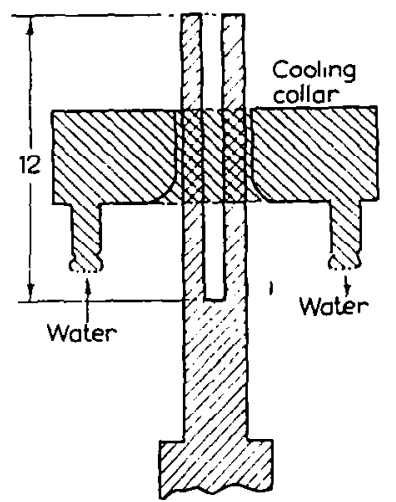

Fig. 2. Watercooled cathode.

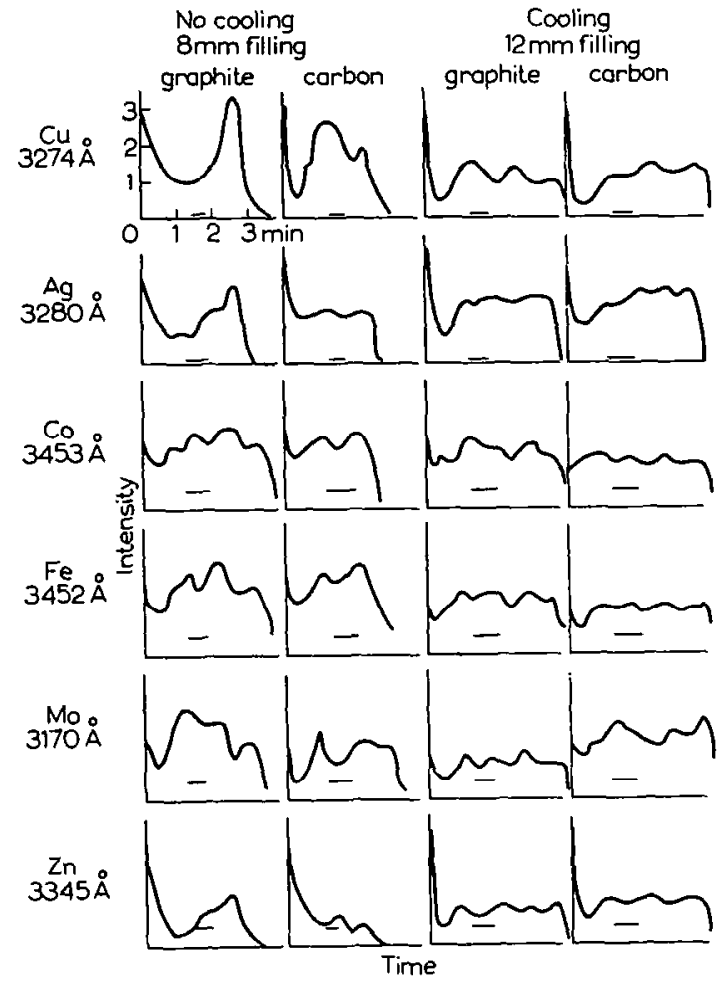

Fig. 3. Line (and background) intensity, with matrix $\mathrm{Al}_{2} \mathrm{O}_{3}+\mathrm{C}$, as a function of time.

(2) The irregularities at the ignition of the arc, such as spluttering of the sample, could sufficiently be counteracted by covering the filling with a collodion film as is describer by Staliwood [5].

(3) A more important source of error proved to be unequal evaporation and thus separation of the components of the sample by too strong heating of the lower purt of the cuthule-filling during the exposure. This occurred indeed with our electrode form, especially with graphite electrodes. The difficulty was eliminated by means of a small collar with cooling writer. clusely fitting around the cathorle at a constant distance below the burning spot (Fig. 2). Csing this collar we can expect that, when after some time there is a stationary evaporation, this will stay 


\section{F. A. Hoens and J. A. Smit}

until the end of the filling has passed the cooling collar. We choose a filling length of $12 \mathrm{~mm}$ to get a long stationary time. Fig. 3 shows for $\mathrm{Cu}, \mathrm{Ag}, \mathrm{Co}, \mathrm{Fe}, \mathrm{Zn}$, and $\mathrm{Mo}$ examples of the spectral intensity as a function of time in an arc without cooling and with cooling, for graphite and carbon. Apparently the cooling resulted in a more constant evaporation of the sample substances, except during the first minute.

(4) Other irregularities of the d.c. arc procedure, such as wandering of the burning spots (with wandering of the cathode-layer) and oblique burning of the filled cathode were not decreased by the cooling, but grew more critical. This was counteracted by rotating the cathode (frequency about 15 c.p.s.) around its axis, which caused a regular cathode burning spot. This resulted in:

(a) Regular symmetrical burning of the cathode and consequently a constant place of the cathode-layer and a better constant distance between cathode-layer and water collar;

(b) Better contact between cooling collar and electrode.

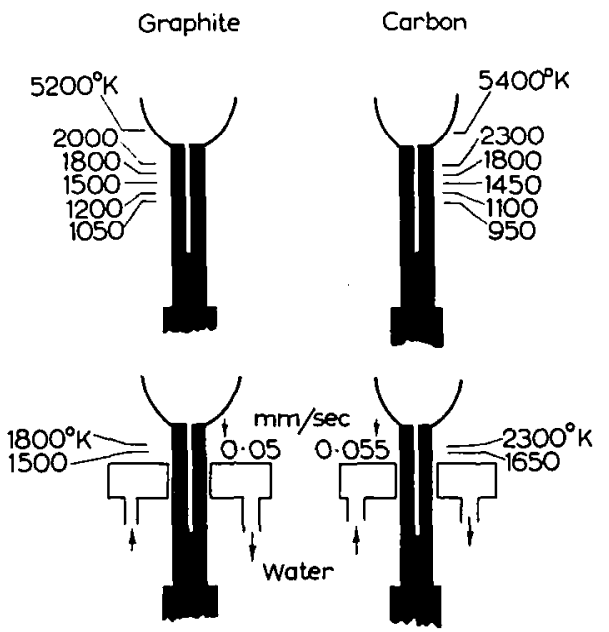

Fig. 4. Temperatures of graphite and carbon cathode. Filling: $\mathrm{Al}_{2} \mathrm{O}_{3}+\mathrm{C}$.

This method made it possible to work with a greater diameter of the filling without a loss in accuracy. The advantage of a greater diameter is an increase of sensitivity.

\section{Discharge conditions}

In a discussion of the best discharge conditions, the following parameters must be taken into account:

(a) Temperatures and burning velocity

Fig. 4 shows the temperatures of the arc and electrodes in a "stationary" burning. The filling in the cathode is a $\mathrm{Al}_{2} \mathrm{O}_{3}+$ graphite matrix. The four cases indicated are the stabilized and unstabilized graphite and carbon arcs. We measured the are temperature via the intensity ratio of CN-band heads $4197 / 4216 \AA$ [6]; accuracy $\approx 200^{\circ} \mathrm{C}$. And we measured the electrode temperatures with an optical pyrometer; accuracy $\approx 50^{\circ}$.

Though the temperatures inside the electrode might be somewhat higher than those of the wall, because of heat conduction from the cathode spot and heat production by the current in the electrode, we can distinctly see differences between graphite (Ringsdorff RW 1 and Johnson Matthey 4B) and carbon (Ringsdorff RW 2). The temperature of the carbon top is higher than that of graphite, but beneath the top of the electrodo it is the reverse. This is a consequence of thermal conduction, which for graphite is about a factor 4 higher than for carbon; in these narowr electrodes more unequal sample-evaporation results in the case of graphite than with carbon. Another consequence is observed in the burning velocity of the electrodes; for graphite it is about $10 \%$ less than for carbon. In the stabilized arc these velocities are constant; in the unstabilized arc they are increasing and will for graphite reach a stationary value only after about $2 \frac{1}{2}$ minutes. 


\section{(b) Cooling collar distance}

Measurements showed an increase of the intensity ratio of $\mathrm{Cu}$ line $3274 \AA$ and its brekground as a function of the distance cathode top-cooling collar. With graphite this incrcase is rather irregular; with carbon it is smooth. The greater the cooling collar distance, the more the intensity ratio approaches the values belonging to the unstabilized "stationary" arc.

The differences between graphite and carbon are distinct and are caused, as explained above, by different heat conduction. From the graphs it appears that carbon is less critical at small cooling collar distance than graphite.

\section{Results}

Table 2a gives a few examples of standard deviations with the unstabilized and stabilized arc. With the stabilized arc we used carbon cathodes (filling diameter $0.9 \mathrm{~mm}$, filling length $12 \mathrm{~mm}$, see Fig. 2). When using the stationary part of the burning period the stabilization causes a large increase of accuracy (cf. last column of Table 2a: optimal moment). The improvement is less distinct if the total intensities (complete evaporation) are used with volatile elements like $\mathrm{Cu}$ and $\mathrm{Zn}$; this is caused by the very unequal evaporation in the beginning of the exposure (see Fig. 2). Both the optimal moment and the complete evaporation yield a distinct increase of intensity with increasing content in the stabilized arc, which was not always the case with the unstabilized arc (Table $2 b$ ).

\section{Remarks}

Other methods for d.c. arc stabilization have been published amongst others by AarTs [7] and Stallwood [5]. Aarts stabilized the arc by means of a coaxial screw-shaped stream of air. STALLwOoD stabilized his arc and sample evaporation by air streaming horizontally towards the filled electrode, after which the air obtained a vertical direction. We have tried to adapt these techniques, but with the cathodelayer method, the former method gave more unequal evaporation and the latter gave an unstable arc.

We tried also some other apparatus to obtain stabilization, but we obtained the best results with the simple water cooling collar and the rotating cathode.

Table 2a. Standard deviation of measured intensity ratio (per cent)

\begin{tabular}{|c|c|c|c|c|c|c|c|}
\hline \multirow{3}{*}{ Arc } & \multicolumn{4}{|c|}{ Photographic } & \multicolumn{3}{|c|}{ Photoelectric } \\
\hline & \multirow[b]{2}{*}{$\begin{array}{l}\text { Number } \\
\text { of meas. }\end{array}$} & \multicolumn{3}{|c|}{ Whole exposure } & \multirow{2}{*}{$\begin{array}{l}\text { Number } \\
\text { of meas. }\end{array}$} & \multirow{2}{*}{$\begin{array}{l}\text { Whole } \\
\text { exposure } \\
\frac{\mathrm{Cu}}{\mathrm{Ag}}\end{array}$} & \multirow{2}{*}{$\begin{array}{l}\text { Optimal } \\
\text { moment } \\
\frac{\mathrm{Cu}}{\mathrm{Ag}}\end{array}$} \\
\hline & & $\frac{\mathrm{Co}}{\mathrm{Fe}}$ & $\frac{\mathrm{Mo}}{\mathrm{Fe}}$ & $\frac{\mathrm{Zn}}{\mathrm{Fe}}$ & & & \\
\hline $\begin{array}{l}\text { Unstabilized } \\
\text { (with graphite } \\
\text { cathode) } \\
\text { Stabilized } \\
\text { (with carbon } \\
\text { cathode) }\end{array}$ & 10 & $2-2$ & $3 \cdot 5$ & 11 & 22 & 11 & 9 \\
\hline
\end{tabular}


Table $2 \mathrm{~b}$. Intensity ratio $\mathrm{Zn} / \mathrm{Fe}$

\begin{tabular}{l|c|c}
\hline Sample & $\begin{array}{c}\text { Unstabilized arc, and } \\
\text { graphite cathode }\end{array}$ & $\begin{array}{c}\text { Stabilized arc, and } \\
\text { carbon cathode }\end{array}$ \\
\hline $22 \% \mathrm{Zn}$ in $\mathrm{Al}_{2} \mathrm{O}_{3}+\mathrm{C}$ & 0.32 & 0.17 \\
$87 \% \mathrm{Zn} \mathrm{in} \mathrm{Al}_{2} \mathrm{O}_{3}+\mathrm{C}$ & 0.37 & 0.52 \\
$78 \% \mathrm{Zn}$ in $\mathrm{Al}_{2} \mathrm{O}_{3}+\mathrm{C}+\mathrm{K}_{2} \mathrm{SO}_{4}$ & $0.0 ?$ & 0.36 \\
\hline
\end{tabular}

\section{References}

[1] Mitcmell R. L. The spectrographic analysis of soils, plants and related materials 1948. [2] Sсотт R. O. Spectrochim. Acta 1950473.

[3] Smit J. Thesis, Utrecht 1952; Smit J. and Smit J. A. Anal. Chim. Acta 19538274.

[4] Boeschoten F. Thesis, Utrecht 1953.

[5] Stallwood B. J. J. Opt. Soc. Amer. 195444171.

[6] Smit J. A. Thesis, Utrecht 1950; Somers P. J. Thesis, Utrecht 1954.

[7] Aarts C. J. M. Thesis, Utrecht 1952.

\section{Discussion}

H. Oosting: (1) Von den beiden Fehlerquellen (chemische Vorkonzentration und Lichtbogen) haben Sie versucht den Bogen auszubessern. War das, weil diese Fehlerquelle die grösste war oder hatte es einen anderen Grund? (2) Sie erklären das unterschiedliche Verhalten von $\mathrm{Co}$ und Mo einerseits und $\mathrm{Zn}$ andererseits indem das $\mathrm{Zn}$ wesentlich flüchtiger ist. Das $\mathrm{MoO}_{3}$ ist aber so flüchtig, dass es sich vielmehr wie das $\mathrm{Zn}$ verhalten müsste.

Antwort: (1) Im allgemeinen kann man nicht sagen welcher der beiden Fehlern grösser ist. In beiden Fällen haben wir zu tun mit systematischen und zufälligen Fehlern, die nicht immer gleich liegen. Wir haben uns der Vorkonzentration distanziert, weil wir das Problem des Bogens nur von der physikalischen Seite studieren wollten. (2) Wir haben keine besondere Schwierigkeiten des $\mathrm{MoO}_{3}$ empfunden. Man muss aber beachten, dass es z.B. schwerflüchtige Molybdate gibt.

H. HoLDT: Sind Versuche mit verschiedenen Bohrungen gemacht worden und sind Fehler dabei geschätzt worden? Wir haben gleiche Versuche gemacht mit gleicher Feststellung.

Antwort: Wir haben nur den Diameter der Füllung geändert. Die Fehler der relativen Intensitäten wurden nicht grösser. Die grösseren Diameter haben wir deshalb gewählt un die Vergrösserung des Verhälthisses Linie zu Untergrund zu studieren. 